\title{
Photocopier industry: at the forefront of servitization.
}

\author{
Filippo Visintin
}

\begin{abstract}
The photocopier industry is undoubtedly one of the forerunners of servitization. The original equipment manufacturers (OEMs) of photocopiers, such as Xerox, pioneered the implementation of servitised business models and, over time, have developed considerable system-integration, application-development and consulting capabilities.

Today, these companies integrate print needs within total ICT solutions and compete against system integrators, consulting firms and software vendors in a large, diverse and growing document management market. This chapter provides a state of the art analysis of servitization phenomenon in the industry as well as a retrospective analysis of its evolution. The chapter ends with a discussion of managerial implications.
\end{abstract}

\section{xy.1 Introduction}

The photocopier industry is one of the forerunners of servitization (Finne et al. 2013, Matsumoto and Kamigaki 2012). The original equipment manufacturers (OEMs) of photocopiers have profited from the sales of services and consumables and pioneered the implementation of servitised business models that are now common practice in many other industries. For example, some of the challenges that photocopier OEMs have faced well in advance of many other manufacturers include the sale of the products' usage instead of the products themselves, the adoption of pay-per-output (pay-per-page) pricing models and the delivery of integrated solutions and outsourcing services (Finne et al. 2013; Visintin 2012).

Today, formerly analogue photocopier OEMs produce connected and digital multifunction devices. Under the heading of managed print services, they also offer integrated solutions that claim to optimise the customer's document-related processes and infrastructure. They compete against (formerly) printer OEMs in a consolidated global multifunction product market. In addition, they compete against system integrators, consulting firms and software vendors in a large, diverse and growing document management market, roughly estimated at over $\$ 130$ billion in 2012 (Xerox 2012). 
The photocopier industry thus undoubtedly represents an interesting setting for studying servitization. Indeed, Xerox Corporation, one of the industry leaders, is considered the epitome of servitised enterprise. It is cited as a case example in a large number of scientific publications (Baines et al. 2007; T. S. Baines et al. 2009a; T. S. Baines et al. 2009b; Geum et al. 2011; Park et al. 2012; Lightfoot et al. 2011; Martinez et al. 2010; Gebauer et al. 2010; Santamaría et al. 2012; Vandermerwe and Rada 1988; Mont 2004; Rapaccini et al. 2013).

This chapter provides a state of the art analysis of servitization phenomenon in the photocopier industry as well as a retrospective analysis, extending 60 years into the past, of its evolution. The chapter is organised as follows. The next section presents the most important evolutionary steps that characterised the industry and their impact on the companies' service strategies. Section 3 explores the most important supply- and demand-related factors driving the ongoing industry expansion into service. Section 4 illustrates the most important features of the OEMs' offerings. Section 5 presents the industry ecosystems, Section 6 shortly illustrates the case of Xerox and, finally, Section 7 presents the conclusions.

\section{xy.2 Photocopier industry servitization: a sixty-year journey}

Today, photocopier OEMs are undoubtedly highly servitised. In recent years, they have developed considerable system-integration, application-development and consulting capabilities. Furthermore, they have responded to the hardware market crisis by consolidating services and solutions and by integrating print needs within a total ICT offering (Visintin 2012). The industry servitization process, however, has not followed a 'forward-unidirectional' (Finne et al. 2013) path. Indeed, in the last 60 years, technological development, business model innovations, regulatory changes and evolving customer needs have alternately boosted and inhibited this process. These evolutions are briefly described in the following subsection.

\section{Xy.2.1 The birth of the modern photocopier and of the first 'servitised' business model}

Photocopier OEMs have always considered the provision of services and supplies as low-risk and long-term sources of revenues (Sampson 2001). Photocopiers feature a large amount of mechanical parts, which more or less ensures that they will inevitably suffer from some form of mechanical failure. This, in turn, creates a stable demand for maintenance services, adding to the demand for supplies (ink and paper) which automatically originate from the product utilization.

Indeed, even in the 1950s, most of the photocopier OEMs had already adopted a 'razor and razor blades' business model (Finne et al. 2013). They applied a modest 
mark-up on their products' cost to keep the selling price low, ensure the product is affordable and expand the installed base. After the customers had purchased the product, the photocopier OEMs sold service parts and supplies at a much higher margin. Given the expensive papers and different types of supplies required by those early copiers, the aftermarket ensured very high, stable and profitable revenue streams (Chesbrough and Rosenbloom 2002).

The photocopier industry, however, was also one of the first industries in which the 'razor and razor blades' business model, based on the provision of product-related services (Tukker 2004), was challenged by an innovative and more servitised business model (Finne et al. 2013) rooted in use-oriented rental services (Tukker 2004). Such a business model was developed in the late 1950s by Haloid Company (as Xerox was called then) to bring the first modern photocopier (Xerox 914 model) to market (Figure 1).

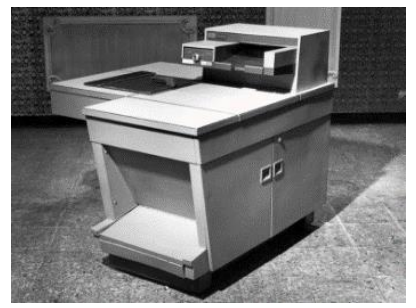

Figure 1 Xerox 914 the first modern photocopier (1959)

In the late 1950s, Haloid Company wanted to commercially exploit the patent, held by Chester Carlson, relevant to the electrophotography process (subsequently renamed xerography, which literally means 'dry writing') (Owen 2004). Contrary to the mimeograph process, which was the previous industry standard, the electrophotography process produced dry copies instead of wet copies, i.e. it allowed for the use of cheap plain paper instead of expensive chemically treated paper. The first device implementing the electrophotography process was the Xerox 914. In addition to the use of plain paper, the Xerox 914 model carried several other advantages. It was much easier to use, more productive, produced higher quality reproductions and carried no risk of damaging the original document (Owen 2004). However, such technological superiority came at a price. The Xerox model 914, in fact, was estimated to cost $\$ 2,000$ to manufacture, while the price of the photocopiers sold by competitors was around $\$ 300$ at the time (Chesbrough and Rosenbloom 2002). Product commercialisation was thus a major challenge. Eastman Kodak, General Electric and IBM all declined Haloid's proposal to establish a partnership to bring the product to market. Even these experienced competitors thought that the superior performance of the Xerox 914 model did not justify an estimated price approximately ten times higher than that of its competitors (Chesbrough and Rosenbloom 2002). To overcome the problem of the selling price, Haloid eventually decided to abandon the dominant 'razor and razor blades' business model and began leasing 
its 914 model at the price of $\$ 95$ per month (Chesbrough and Rosenbloom 2002). Such fixed monthly payments covered all the required services and support - which were delivered exclusively by Haloid - as well as the cost of the first 2,000 copies per month. Additional copies were charged separately at $4 \phi$ per copy. Such a pricing model was indeed very attractive. At that time, the average number of copies per machine was approximately 3,000-4,000 per month; the cost of the chemicallytreated paper required by the competitors' copiers was around $15 \mathrm{c}$ per sheet (Chesbrough and Rosenbloom 2002). Finally, to reduce customers' scepticism regarding this new and innovative offering, Haloid allowed cancellation of the contract with just 15 days' notice (Chesbrough and Rosenbloom 2002).

By employing such a solution, Haloid was able to make the product affordable for a much larger number of customers. This, in turn, led to the birth of a fast-growing and profitable aftermarket in which competitors were completely locked-out. Between 1959, when the Model 914 was introduced, and 1961, Haloid nearly doubled its revenues (Chesbrough and Rosenbloom 2002). As the result of this extraordinary success, the company changed its name to Xerox Corporation in 1961. During the course of the model 914 lifecycle, Xerox manufactured more than 200,000 units and its revenues grew from $\$ 30$ million in 1959 to $\$ 2.5$ billion in 1972 (Chesbrough and Rosenbloom 2002). In 1972, the company controlled $60 \%$ of the photocopier market and $95 \%$ of the plain paper photocopier business (Kearns and Nadler 1992). This dominance, however, led the Federal Trade Commission to issue an antitrust suit against Xerox in January 1972 for alleged monopolization of the office photocopier market (Tom 2001). As a result of this anti-trust suit, Xerox was forced to take the following actions in 1975: (i) license the company's entire patent portfolio for a small royalty; (ii) offer the model 914 (also) for sale; and (iii) allow competitors to provide services and toners for its products (Tom 2001; Chesbrough and Rosenbloom 2002). These changes implied a return to the pre-1959 'razor and razor blades' business model. A formerly integrated solution was unbundled and products and services were commercialised separately in a market in which Xerox was no longer a monopolist (Finne et al. 2013).

The first companies to enter this newly created market were IBM and Kodak (Markides 1999). Both of these US-based companies challenged Xerox in the (highend) corporate reproduction market, the segment where Xerox was undoubtedly stronger. This segment was characterised by critical, high-speed and complex-torepair products whose unavailability could create significant problems for customers. As a result, customers were less sensitive to the price of maintenance services, which were indeed overpriced. The strategy adopted by IBM and Kodak involved conquering market share by offering better products and/or better maintenance services at lower prices (Ortt 2007). However, their strategy failed, mainly because of the huge loyalty of Xerox's corporate customers (Markides 1997). Nonetheless, between 1976 and 1982, the U.S. industry's global market share fell from $82 \%$ to 41 $\%$. Such a dramatic drop was due, in large part, to the success of Japanese companies (Rogowsky 2009) and their 'service-free' photocopiers (Boulton 1996; Johnstone 2004). 


\section{Xy.2.2 The growth of Japanese competitors and the 'service-free' office photocopier}

The growth of Japanese competitors, such as Canon, Ricoh, Sharp, Minolta, Panasonic, Toshiba and Konica characterised the second half of the 1970s and the 1980s. Contrary to IBM and Kodak, the Japanese did not challenge Xerox in the high-end market. Their strategy, instead, was to first gain market share in the low end of the market, a segment where Xerox was weak, and then move up. Xerox machines were big, complex and tended to fail quite often (Johnstone 2004), characteristics that Xerox exploited by charging for service calls. Japanese OEMs realised that in order to challenge Xerox, they had to produce smaller, cheaper and virtually 'service-free' photocopiers.

Canon was probably the most successful company in implementing this strategy. Canon's revolutionary intuition was to include all the photocopier's key components - drum, charger, toner and cleaner - in a replaceable cartridge (Johnstone 2004) (Figure 2). Such a solution made it possible, even for unskilled people (and thus also for customers), to replace spare parts and perform simple repairs (Ortt 2007).

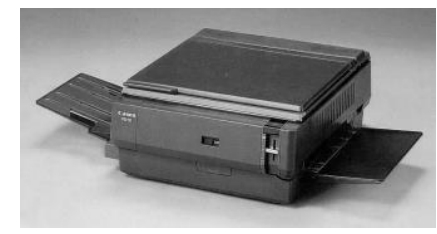

Figure 2 Canon PC-10, the world's first personal photocopier with replaceable cartridges (1982).

A simplified design, coupled with the application of innovative production techniques, such as lean manufacturing, cell production and just-in-time inventory practice allowed Canon to produce extremely affordable and reliable products (Boulton 1996; Rogowsky 2009). Canon (as well as the other Japanese OEMs) was able to cut costs on warehouse facilities, shorten product lead times, assemble products that had fewer manufacturing defects and establish production lines in less time than their counterparts in the U.S. (Boulton 1996). In addition, to weaken Xerox's customer loyalty, Canon also developed an innovative distribution and service strategy. Instead of establishing a direct sales and support channel, Canon distributed its products in each country through a capillary network of small office products dealers and retailers (Markides 1999). These local dealers were also responsible for providing service and support (Boulton 1996), which, given the simplified product design, was not a daunting task.

Hence, while Xerox emphasised the high productivity of its machines, the competence of its direct sales force and its superior service, Canon concentrated on the affordability, reliability and ease of use and repair as its differentiating features (Markides 1999). With a growing product base, Japanese competitors moved up 
market into mid-volume machines. By 1985, Canon had become the world's leading photocopier company. Xerox attempted, without success, to enter this mass market, but in 2001 decided to stick to the high-end market segment (Ortt 2007).

With the advent of the personal office photocopier, the relative strategic importance of services in the industry, on average, decreased. Companies still used the 'razor and razor blade' business model, but most of their profits came from the sale of cartridges as services were residual (Ortt 2007). Indeed, services remained an important source of profit and differentiation in the high-end segment. For these complex and critical products (production printers, wide format equipment, etc.), customers still needed highly skilled representatives to be dispatched within a few hours of notification and were willing to pay for their services (Visintin 2012).

\section{xy.2.3 The digitisation of the document workflow and the shift towards the solutions business}

In the 1990's, another major product innovation set the stage for a new shift towards more servitised business models. During this period, analogue products were replaced with digital products (Visintin, 2012). With analogue technology, the document/image is projected directly onto a photosensitive drum through an optical system, without being digitised. With digital technology, a light coming from a copy lamp is reflected by the document and passed through the lens to the charged coupled device (CCD) sensor. The CCD sensor converts the photo signal into an electrical signal (digitisation). Once the image scanning is completed, electrical signals are converted back into photo signals and the image is subsequently printed. Among other benefits (i.e. an increase in the machine's reliability), digital technology allows copiers to digitise, save, store and distribute the image/document being scanned, thereby creating a digital workflow. To exploit the opportunities arising from the digitisation of document workflow and from the diffusion of network technologies, copier manufacturers started to equip their devices with controllers. Controllers allow connection to a network and, through the network, to different terminals from which the photocopiers can be operated (Visintin, 2012). Former analogue photocopiers thus became connected digital multifunction devices (Figure 3) combining the functions of a photocopier, printer, scanner and fax machine into a single device (Matsumoto and Kamigaki 2013). 


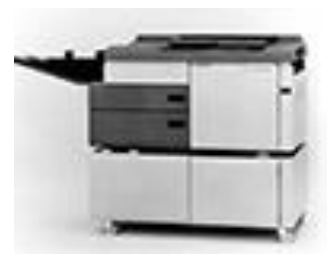

(i)

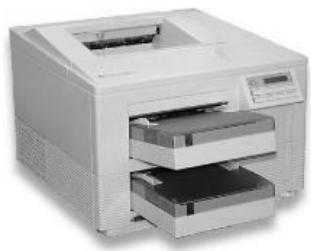

(ii)

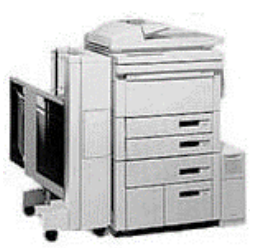

(iii)

Figure 3 (i) Xerox Printer 100, the world's first machine incorporating print and copy functions (1987); (ii) HP LaserJet IIISi, the world's first networked printer (1991); (iii) Canon GP the world's first 'true' multifunction device (1994)

The digitisation of the photocopier had two major implications. First, it increased the number of competitors in the market. Companies traditionally producing smaller and cheaper printers, such as HP, Samsung and Lexmark, started to produce multifunction devices as well (Matsumoto and Kamigaki 2013; Rogowsky 2009). Second, these multifunction devices became part of the customer ICT infrastructure and, as such, enablers of several processes (printing, scanning, archiving, mailing, faxing, etc.). Both of these developments increased the momentum of the servitization of the whole industry. On the one hand, the hardware market became more price-sensitive. On the other hand, companies realised that in order to bring more value to customers, establish long-term relationships and increase profits, they would need to expand their offerings from just selling and maintaining hardware products to providing solutions ensuring the optimization of the processes that these products enabled (Visintin 2012).

Xerox Corporation was the first company to offer this type of solution for the U.S. market in the second half of the 1990s (Matsumoto and Kamigaki 2013). Since then, external and internal stimuli have encouraged almost all the major photocopier OEMs to venture into the solution business. Delivering solutions, however, is far from simple. It requires implementing a new, more customer-oriented, relationshipbased business model (Spring and Araujo 2009; T. Baines et al. 2009). It also requires the manufacturer to develop new competences (Oliva and Kallenberg 2003; Davies et al. 2007; Storbacka 2011; Paiola et al. 2013). Indeed, some OEMs have succeeded in the transition while others are still transitioning and/or lagging behind (Weilerstein and Drew 2012; Le Clair 2012; Fernandes and Longbottom 2012b; Muscolino 2011). The next section analyses the forces that are driving this ongoing transition. 


\section{xy.3 Supply and demand-related factors influencing the ongoing servitization of the photocopier industry}

Photocopier OEMs are increasingly servitizing their business models in response to the following factors: (i) new and untapped customer needs; (ii) a flat hardware market and (iii) decreasing print volumes.

\section{xy.3.1 New and untapped customer needs}

Nowadays, many organizations use a vast amount of photocopiers, printers, fax machines and scanners. Typically, these devices are sourced from different vendors at various points in time in order to meet the contingent needs of different departments or individuals. This fact, especially for large organizations, determines the proliferation of redundant and/or outdated equipment, unmanaged document workflows and the burden of dealing with many different types of devices and service contracts. It, in turns, causes ever-growing indirect administrative and logistic costs, paper and energy wastages as well as security and environmental concerns. The printing processes are thus increasingly becoming non-core critical processes. In fact, they consume a considerable amount of resources and have a strong influence over other core and non-core processes. Companies, however, usually lack the resources and competences needed to manage printing process efficiently and often prefer to divert their limited resources to core activities. As a result, they are usually willing to resort to external suppliers. The needs that these suppliers are expected to satisfy can be synthesised as follows.

Reduce the printing environment costs. Companies are increasingly more aware of the direct and indirect costs driven by their copying/printing devices. Hence, they need help to quantify and reduce these costs.

Increase control. Companies need a visible record of their printed output for accounting and control purposes. On the one hand, they need to allocate accurately the printing costs to specific departments or cost-centres. On the other hand, they need to control the print volume and enforce printing restrictions. The control issue is even more complex for those companies adopting 'bring your own device' (BYOD) policies. These policies allow employees to bring personally owned mobile devices (laptops, tablets and smart phones) to their workplace where they can use them to access privileged company information and applications. These policies expand the printing environment to mobile and home workers, thereby driving the need for solutions that allow users to print from mobile devices and companies to control such printing.

Increase security. Customers need to increase the security of their printing processes. Once documents are printed, they are nearly impossible to track. Conse- 
quently, documents left unattended or unclaimed in a printer output tray can represent a major security risk. The data temporarily stored in a multifunction device's hard drive can increase security concerns as well. In certain cases, this need for secure printing is driven by the necessity to comply with directives such as the Health Insurance Portability and Accountability Act (HIPAA), the Markets in Financial Instruments Directive (MIFID) and the Sarbanes-Oxley Act, among others. All of these directives contain security requirements associated with the document output activities.

Increase environmental sustainability. Customers need to increase the environmental sustainability of their business; hence, they need help to define and implement responsible printing polices and to assess and certify the benefits of these policies (e.g. in terms of carbon footprint).

\section{xy.3.2 Flat hardware market}

The printing hardware market is characterised by decreasing sales, falling prices and shrinking margins (Brewer 2009), especially in EMEA and in the U.S (IDC 2013; Shah et al. 2013). Throughout 2012 the EMEA multifunction market experienced a $12 \%$ unit decline (Shah et al. 2013); similarly, the U.S. experienced a $9.8 \%$ unit decline (Kim et al. 2012). Device saturation and reduced consumer demand owing to the global economic recession in 2008 have led to declining global spending on hardware (Rogowsky 2009). Recovery to pre-crisis levels is expected to be slow (Rogowsky 2009; Brewer 2009). Moreover, the commoditization of hardware is creating unprecedented price pressure and constantly shortening the lifecycle of new products. This, in turn, calls for a regular flow of new models and types, which have to be attractively priced. The search for scale benefits and the need to develop product platforms that serve as a basis for bringing new products to market as fast as possible is evidenced by the rapid consolidation of the industry (e.g. in the last two decades, Ricoh acquired Savin, Gestetner, Lanier, Rex-Rotary, Monroe, Nashuatec and IKON Office Solutions; similarly, in 2010, Canon acquired Océ, the largest European manufacturer of printers).

\section{xy.3.3 Decreasing print volumes}

In the past, the lower margins associated with hardware sales were tolerated in light of the substantial profits coming from the sales of consumables and break-fix services. Unfortunately, print volumes, which drive the demand for consumables and break-fix services, are shrinking as well. According to IDC, in 2011, the total number of printed pages (3.09 trillion pages A4) decreased by $1 \%$ compared to 2010 (IDC 2012). In the same fashion, Gartner estimates a reduction in printed, 
copied and faxed pages of approximately $50 \%$ during the past six to seven years (Weilerstein and Drew 2012). This decrease is certainly due to the digitisation of document workflows. However, it has been accelerated by other factors, including (Weilerstein and Drew 2012) the following: the diffusion of larger displays; environmental initiatives undertaken by individuals, enterprises and governments; generational turnover (workers who grew up with the PC and the Internet print less than those who did not) and the diffusion of tablets and smartphones.

\section{xy.4 The photocopier industry's integrated solutions: the managed print services}

All the most important photocopier OEMs have responded to the developments presented in the previous section by consolidating services and solutions (Visintin 2012). Managed print services (hereafter MPS) are the industry buzzwords used, quite often inappropriately, to identify the integrated solutions built around multifunction devices. These solutions are indeed very heterogeneous. They span from simple bundles of multifunction devices plus a maintenance contract to complex enterprise-wide solutions encompassing a variety of hardware, software components and a full set of services. By 2013, MPS are expected to account for $35 \%$ of total revenues in the global multifunction product industry (Kidambi 2013).

In general, MPS can be defined as solutions aiming at optimizing and managing the customers' document output environment. Such an environment includes photocopiers, scanners, printers and fax machines, as well as their consumables and outputs, the processes that these devices enable (mailing, scanning, copying, faxing, archiving, distributing, sharing) and the people involved in these processes. The document output environment can be limited to the office environment or extended to mail/print rooms, corporate reprographics departments, datacentres, as well as home workers and mobile workers. With MPS, the supplier takes on the responsibility to supply the hardware equipment (which may replace or add up to the hardware that the customer already owns) as well as the software and services required to operate them efficiently.

MPS are usually regulated by multiyear contracts. Some contracts include guarantees of certain outcomes and oblige the customer to act according to the supplier's policies. Depending on the type of contract, customers can purchase, rent or lease the hardware. In any case, customers are usually charged a pay-per-page fee that covers the supplies, the service and the cost of the equipment. Certain contracts require a minimum number of pages per device per month, with unused pages forfeited. Other contracts do not set a monthly minimum, instead charging customers a price per page that decreases as the print volume increases. However, when no limits are set, customers are still charged a flat fee (e.g. a per-device fee or a perseat fee). Sometimes, services are billed separately, applying a monthly or quarterly flat fee. Historically, MPS customers are large enterprises. Nonetheless, the most 
important MPS providers are developing specific downsized offerings for small and medium business as well (Fernandes and Longbottom 2012a).

The MPS solution is comprised of several hardware, software and service 'components'. These components are briefly described hereafter.

\section{xy.4.1 Hardware}

Hardware usually includes office printing and scanning devices (typically multifunction devices). In certain cases, it can also include production printing devices (those used in mail/print rooms and corporate reprographics departments) as well as wide format (larger than $\mathrm{A} 3$ ) devices.

\section{xy.4.2 Software}

Software includes machineware, utilities and applications (Visintin, 2012). Machineware provides the minimum functionality to operate the hardware in compliance with common market practices. Utilities enable end-users to utilise the machine (e.g. universal location-aware drivers). Finally, applications add value and/or extra functionalities to the customer and extend the usage options of the customer. These extended functionalities include the following: (i) Pull and secure printing, i.e. the capability to hold print jobs on a server and release them only when the user authenticates herself at a printer using a pin code, smartcard or fingerprint reader. The job can be released at any printing device supporting this feature. Print jobs can also be encrypted before being released. (ii) Mobile printing, i.e. the possibility to print from tablets and smartphones using a mobile application or via email. (iii) Usage tracking, i.e. the possibility to track the utilisation level of each device as well as the printing volumes and behaviours of individuals, departments or other workgroups. (iv) Rules-based control, i.e. the possibility to control the attributes (type, paper size, media type, colour, definition and duplexing) of the documents that can be printed from each account, and/or the possibility to automatically delete, hold or reroute print jobs to the most suitable printer (e.g. a cheaper black and white printer for a high volume text-based document or the print room production printer for more complex jobs). 


\section{xy.4.3 Services}

Services can be classified as follows: (i) assessment, (ii) design, (iii) implementation, (iv) education, (v) improvement, (vi) support, (vii) environmental, (viii) financial and (ix) business process management.

i. Assessment services. These services are intended to identify the current number of devices installed at the customer's site and estimate the volume of pages printed. In the simplest situations, these data are self-reported by customers. When conducting a more thorough assessment, the supplier maps the number of devices installed at each floor/building and surveys the end-users to understand what is being printed, on what type of media and by whom. In addition, the supplier analyses the document workflows and the document environment infrastructure. Such an analysis can also include environmental and security risk assessments. In-depth assessment could require up to three months and the utilization of dedicated software.

ii. Design services. Based on the assessment, the supplier defines the hardware, software and services needed to achieve agreed on performances. Depending on the case, optimization services can also include a thorough reengineering of the document-related processes. The solution designed typically consists of an upgraded fleet with a new layout and will likely involve new printing and imaging devices, new software and new printing policies.

iii. Implementation services. These services allow the deployment of the designed solution. New devices and software are installed and existing devices are redeployed or removed. The whole process is carried out following a deployment plan, with precise deliverables and milestones agreed on with the customer.

iv. Education services. These consist of training activities ensuring that end-users (and, in general, all the stakeholders) have the necessary skills and knowledge to benefit from the implemented solution. Attendees are taught how new devices and software applications work, how to maximise productivity and reduce waste and how to ask for support. Education programs can also address environmental issues.

$\mathrm{v}$. Improvement services. These include the control and fine-tuning of the document output environment over time to meet the agreed upon service level agreements or key performance indicators. They can also include installing, moving, adding, changing and disposing (IMAC/D services) devices in order to update the fleet and/or accommodate changes in the customer's IT infrastructure and environmental policies.

vi. Support services. These typically include a centralised help desk, on-site support and supplies replenishment; more sophisticated solutions also include remote monitoring services. With these services, the supplier monitors low toner and equipment issues, delivers firmware updates, configures network devices and provides a web-based portal through which the customer can 
monitor the fleet performance. These services are usually associated with proactive supply replenishment.

vii. Environmental services. With these services, the supplier not only helps customers to reduce paper and power consumption, but also supports the customer's environmental sustainability initiatives by suggesting various alternative energy solutions, including solar panel installation, reforestation or carbon credit purchases. They supplier can also provide the customer with a carbon offset certificate(s).

viii. Financial services. These include financing, leasing and rental services.

ix. Business process management services. With these services, the supplier takes on the responsibility to manage one or more of the customer's processes on its behalf. The managed processes are usually noncore, time-consuming and transaction-based processes, including payroll, accounts payable, mortgage processing as well as several other industry-specific activities (annual student registrations, patients tracking, etc.).

\section{xy.4.4 The solutions spectrum}

To address the heterogeneous needs of different types of customers, OEMs have devised scalable offerings and developed delivery frameworks (Océ's approach is thoroughly described in (Visintin 2012)) to design, deploy and support their solutions. All of these solutions are loosely referred to as MPS. Indeed, they can include only a small portion of the aforementioned components and address very different types of customer segments. While basic MPS are offered by almost all the industry players, advanced MPS are offered only by a few leading companies. The characteristics of the different types of solutions are summarised in Table 1.

It is worth noting that, while the advent of MPS created new business opportunities for the printer/photocopier OEMs, it also introduced new competitors. As already mentioned, delivering MPS requires system-integration, application-development and consulting capabilities. It creates business opportunities for several other actors (system integrators, software vendors, consultancy firms, etc.) other than the OEMs. These actors cooperate and/or compete with the OEMs in a rather complex ecosystem that is described in the next section. 
Table 1 The solutions spectrum

\begin{tabular}{llll}
\hline & $\begin{array}{l}\text { BASIC } \\
\text { solutions }\end{array}$ & $\begin{array}{l}\text { INTERMEDIATE } \\
\text { solutions }\end{array}$ & $\begin{array}{l}\text { ADVANCED } \\
\text { solutions }\end{array}$ \\
\hline Customer need & $\begin{array}{l}\text { Trouble-free utiliza- } \\
\text { tion of one or a few } \\
\text { devices }\end{array}$ & $\begin{array}{l}\text { Optimised document } \\
\text { output environment }\end{array}$ & $\begin{array}{l}\text { Better value proposi- } \\
\text { tion for their busi- } \\
\text { ness }\end{array}$ \\
\hline Value proposition & $\begin{array}{l}\text { Shift from several } \\
\text { transactional pur- } \\
\text { chases to one con- } \\
\text { tract; shift from cap- } \\
\text { ital expenditure } \\
\text { spending to more } \\
\text { predictable opera- } \\
\text { tional expenses }\end{array}$ & $\begin{array}{l}\text { Manage and opti- } \\
\text { mise the entire fleet } \\
\text { of devices under } \\
\text { contract }\end{array}$ & $\begin{array}{l}\text { Manage and opti- } \\
\text { mise the entire docu- } \\
\text { ment-output envi- } \\
\text { ronment and } \\
\text { improve business } \\
\text { processes under con- } \\
\text { tract }\end{array}$ \\
\hline Services offered & $\begin{array}{l}\text { Supplies, basic as- } \\
\text { sessment service, } \\
\text { basic support ser- } \\
\text { vices, financial ser- } \\
\text { vices }\end{array}$ & $\begin{array}{l}\text { Assessment, design, } \\
\text { implementation, ed- } \\
\text { ucation, improve- } \\
\text { ment, support, envi- } \\
\text { ronmental and } \\
\text { financial service }\end{array}$ & $\begin{array}{l}\text { All the preceding } \\
\text { plus business pro- } \\
\text { cess management } \\
\text { services }\end{array}$ \\
\hline $\begin{array}{l}\text { Scope } \\
\text { One or a few devices }\end{array}$ & $\begin{array}{l}\text { The document out- } \\
\text { put environment }\end{array}$ & $\begin{array}{l}\text { The whole document } \\
\text { output environment } \\
\text { and several business } \\
\text { processes }\end{array}$ \\
\hline $\begin{array}{l}\text { Customer-supplier } \\
\text { relationship }\end{array}$ & Out-tasking & Out-sourcing & High \\
\hline Curation of the & Short & Medium & Long \\
\hline & Medium & Partnership \\
\hline
\end{tabular}

\section{xy.5 The integrated solutions competitive landscape}

The photocopier industry's integrated solutions competitive landscape includes the following: (i) OEMs, (ii) systems integrators, (iii) consulting firms, (iv) technology specialists, (v) value-added resellers/dealers and (vi) office supplies retailers.

i. OEMs usually shape their offerings around their own products, although they also provide multivendor support as well. The most important vendors in this category include Canon, HP, Kyocera, Konica Minolta, Lexmark, Ricoh, Toshiba and Xerox/Fuji Xerox. Other players, such as Dell, Sharp, Samsung, Brother, Oki Data and Epson are developing their own MPS offerings as well (Weilerstein and Drew 2012; Le Clair 2012; Fernandes and Longbottom 2012b; Muscolino 2011). 
ii. Systems integrators can either partner with OEMs in delivering MPS solutions in certain markets/industries and/or can offer vendor-agnostic MPS solutions as part of wider managed service contracts (e.g. IBM, Accenture, Capgemini, etc.).

iii. Consulting firms, like system integrators, develop vendor-neutral MPS solutions but usually specialise in specific regions or market segments (e.g. healthcare, architecture, engineering and construction, legal).

iv. Technology specialists provide solutions enabling specific advanced features, such as mobile printing and secure printing. These solutions can include both hardware and software elements but exclude the actual copying/printing devices. Specialists are thus often partners of generalist MPS providers, which use these extra features to add value to their offerings.

v. Value-added resellers / dealers deliver downsized MPS solutions for small and medium businesses. Hence, they are leveraged by the OEMs as a channel to reach small and medium business customers. Local VAR/dealers, in addition to being located physically close to customers, are familiar with the technology and IT environment employed by these companies. VAR/dealers usually must be certified by the OEMs and need to undergo specific MPS training programs (Fernandes and Longbottom 2012a) to obtain the certification.

vi. Office supplies retailers, especially those in the U.S. (e.g. OfficeMax, Staples or Office Depot) have developed their own MPS offerings.

It is worth noting that while competitors coming from different sectors are expanding into the MPS business, leading OEMs are expanding into business process management (BPM), business process outsourcing (BPO) and/or the IT outsourcing business. This should not be surprising. Providing MPS, in fact, affords a good understanding of the customer's IT infrastructure and of their non-core processes, such as IT, accounting and payroll. Leading providers of MPS are thus leveraging their experience and reputation as MPS providers to compete in the managed service business as well. This strategic intent is clearly demonstrated by the number and magnitude of the acquisitions made by some of the most important OEMs in the industry. Some examples include HP's acquisition in 2008 of EDS (now HP Services, a $\$ 22$ billion multinational system integrator and provider of IT outsourcing service); Xerox's acquisition in 2010 of ACS (a \$6.4 billion multinational provider of diversified business process outsourcing and information technology solutions) and Lexmark's acquisition of Perceptive Software in 2010 and of Pallas Athena in 2011 (providers of enterprise content management and business process management solutions, respectively). 


\section{xy.6 A case example: Xerox Corporation}

Xerox Corporation is considered one of the most successful examples of servitised companies. Indeed, Xerox no longer qualifies itself as a photocopier OEM but as an 'enterprise for business process and management' (Xerox 2012). Few key figures provide sufficient clarity regarding Xerox's involvement in the service business and of how such involvement is going to increase in the near future.

In 2012, Xerox's total revenue was $\$ 22.39$ billion. Approximately $84 \%$ of this revenue were annuity-based revenues coming from contracted services, equipment maintenance, consumable supplies and financing services (Xerox 2012). The remaining $16 \%$ came from equipment sales (either from lease agreements that qualify as sales for accounting purposes or outright cash sales). Annuity-based revenue has driven the growth of Xerox's revenues in recent years whereas the equipment sales have flattened (Figure 4).

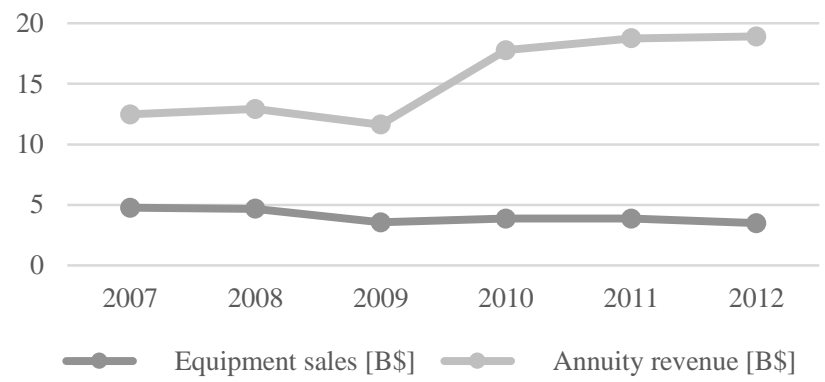

Figure 4 Xerox's revenue streams (source: Xerox 2012)

The most important business segments in which Xerox operates are business process outsourcing, information technology outsourcing and document management (Figure 5)

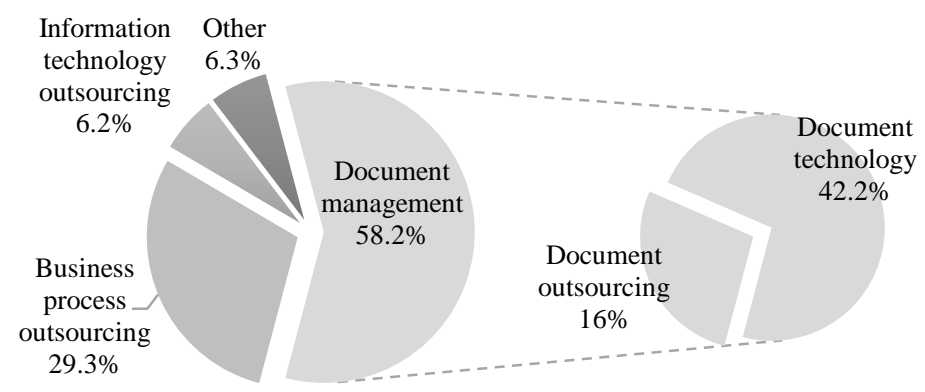

Figure 5 Xerox 2012 revenues by business segment (Xerox 2012). 
The business process outsourcing segment accounted for $\$ 6.57$ billion $(29.3 \%)$ and comprises a diversified portfolio of services, including customer care services, healthcare claims reimbursement services, accounting services and human resource services, just to mention a few.

The IT outsourcing segment accounted for $\$ 1.38$ billion $(6.2 \%)$ and includes mainframe and server outsourcing, network outsourcing and cloud services.

The document management segment accounted for around \$13.04 billion (58.3 $\%$ of the grand total). This market is comprised of document systems, software, solutions and services. Such a segment is subdivided into the following two components: document outsourcing and document technology. The former accounted for $\$ 3.574$ billion $(16 \%)$ and for the most part is driven by the MPS, a business where Xerox is undoubtedly one of the market leaders. The latter accounted for $\$ 9.46$ billion $(42.3 \%$ ) and includes the sale of products (those not provided under a document outsourcing contract) and supplies as well as the associated technical services and financing.

Altogether, in 2012, outsourcing services (business process outsourcing, IT outsourcing and document outsourcing) accounted for $52 \%$ of Xerox's total revenue. The growth of Xerox's service business was sustained, in recent years, by the acquisitions of a number of service and solutions providers around the world (Table 2).

Table 2 Xerox's most relevant acquisitions between 2010-2012 (Xerox 2011, 2012)

\begin{tabular}{|c|c|c|}
\hline Month & Company & Services/solutions provided \\
\hline Feb-10 & $\begin{array}{l}\text { Affiliated Computer Ser- } \\
\text { vices, Inc. ACS }\end{array}$ & $\begin{array}{l}\text { Diversified business process outsourcing and infor- } \\
\text { mation technology services }\end{array}$ \\
\hline Jul-10 & $\begin{array}{l}\text { Excellerate HRO, LLP } \\
\text { ('EHRO') }\end{array}$ & Benefits administration and relocation services \\
\hline Oct-10 & $\begin{array}{l}\text { TMS Health, LLC } \\
\text { ('TMS') }\end{array}$ & $\begin{array}{l}\text { Customer care services to the pharmaceutical, bio- } \\
\text { tech and healthcare industries }\end{array}$ \\
\hline Nov-10 & $\begin{array}{l}\text { Spur Information Solu- } \\
\text { tions, Limited ('Spur') }\end{array}$ & Parking enforcement computer software \\
\hline Apr-11 & Unamic/HCN & Customer care service in the Benelux region \\
\hline May-11 & NewField IT & Print consultancy and software solution (UK-based) \\
\hline Jul-11 & $\begin{array}{l}\text { Education and Sales Mar- } \\
\text { keting, LLC ('ESM') }\end{array}$ & $\begin{array}{l}\text { Outsourced enrolment management and student } \\
\text { loan default solutions }\end{array}$ \\
\hline Nov-11 & The Breakaway Group & $\begin{array}{l}\text { Cloud-based service simplifying the adoption of } \\
\text { electronic medical records }\end{array}$ \\
\hline Jul-12 & $\begin{array}{l}\text { Wireless Data Services } \\
\text { ('WDS') }\end{array}$ & $\begin{array}{l}\text { Telecommunications technical support and consul- } \\
\text { tancy services (UK-based) }\end{array}$ \\
\hline Jul-12 & Lateral Data & E-discovery technology (US-based) \\
\hline Jan-12 & LaserNetworks Inc. & MPS solutions \\
\hline Jan-12 & XL World & Multilingual customer care services (Italy-based) \\
\hline
\end{tabular}


As a result of these acquisitions, Xerox plans to extend its service to two-thirds of its total revenue by 2017 (Xerox 2012). However, to date, notwithstanding the importance of outsourcing services, the sale of products and of the relevant technical services and supplies still account for $42 \%$ of Xerox's total revenues.

\section{xy.7 Conclusions and managerial implications}

The history of the photocopier industry, as well as the business model adopted by its leading OEMs, can help us draw some important conclusions.

First, highly profitable and servitised market offerings can be made unattractive by innovations improving the products' reliability and ease of use. What happened in the 1980s in the photocopier market, i.e. smaller, cheaper and more reliable products that replaced bigger, complex, service-demanding products, could happen again in other industries. The consumerisation of IT (Moschella et al. 2004) is an example of this trend. Consumerisation is the current tendency for new IT to emerge first in the consumer market and then spread into the business-to-business market. One of the consequences of consumerisation is that people are becoming increasingly self-sufficient in meeting their IT needs. Today, several products have become easier to use, and cloud-based, software-as-a-service offerings are addressing an increasing number of business needs in areas such as video-conferencing, digital imaging, business collaboration, sales force support and systems back up, just to mention a few. These products clearly represent a threat for those companies providing integrated solutions in these business areas.

Second, service opportunities emerge when products are critical and customers find it difficult to use and maintain them. The Japanese assault on the photocopier market in the 1980s with 'service-free' products did not target the high-end segment, where superior service performance was still an order winner; rather, it targeted the low-end segment, where service was almost no longer needed. When products are simple, customers learn how to use them and low-cost third-party service suppliers learn how to maintain them. Consequently, both service volumes and profitability inevitably decrease. One way to increase the products' criticality and complexity is to connect them. When low-end office photocopiers became connected multifunction devices, they became part of a more complex and critical system (the company's ICT infrastructure) that customers were no longer able to manage optimally. This opened a huge business opportunity for MPS providers. Similar trends are now emerging in many other industries. In fact, an increasing number of products are becoming connected, and IT-based technologies and new software are extending the functionalities and performance of these goods (Neely 2009; Penttinen and Palmer 2007; Shepherd and Ahmed 2000). Suppliers can thus extend their service business by offering to manage and support not only the product sup- 
plied, but also the entire complex system (made of hardware, software and networks) within which the product operates, as well as the processes that such a system enables (Davies et al. 2007).

Third, product services can also become commoditised (Sampson 2013). In the office photocopier market, for example, break-fix services are now commodities. Basic MPS services are becoming commodities as well. The number of companies providing intermediate and advanced MPS solutions is also increasing. Leading photocopier OEMs are reacting to this trend by expanding their offering to services that are only marginally related with the product they manufacture (e.g. business process outsourcing services). This type of expansion could be successful in other types of business as well. Indeed, the experience and the reputation gained by supporting customers in closely product-related processes are invaluable assets when companies decide to diversify into non-product-related business. Nonetheless, the growth into non-product-related business requires significant investments to develop the required knowledge and capabilities (Fischer et al. 2010; Matthyssens and Vandenbempt 2010). A wise way to acquire these capabilities is through merge and acquisition, which is the approach adopted by many of the photocopier OEMs. The redeployment of a labour force with a strong knowledge about the product and the related process but no experience in the new businesses can, in fact, be very risky (Sampson 2013).

Finally, the example of the photocopier industry suggests that succeeding as a solution provider does not necessarily require shifting from solely providing goods and the related support services to delivering highly integrated and customised solutions (Visintin 2012). Instead, it suggests that companies need to develop the capability to provide modular and scalable solutions to address customers with different types of needs as cost-effectively as possible (Visintin 2012). As the case of Xerox demonstrates, even when companies are highly servitised, the transactional sale of products, supplies and maintenance services can still represent a substantial source of revenues and profits.

\section{Acknowledgment}

The author is grateful to the ASAP Service Management Forum (www.asapsmf.org), an Italian research and dissemination initiative. In particular, the author is grateful for the insights provided by the managers involved in the ASAP's 'Business Process Outsourcing' Focus Group.

\section{References}

Baines, T., Lightfoot, H., Peppard, J., Johnson, M., Tiwari, A., Shehab, E., et al. (2009). Towards an operations strategy for product-centric servitization. International Journal of Operations \& Production Management, 29(5), 494-519.

Baines, T. S., Lightfoot, H. W., Benedettini, O., \& Kay, J. M. (2009a). The servitization of manufacturing: A review of literature and reflection on future challenges. Journal of Manufacturing Technology Management, 20(5), 547-567. 
Baines, T. S., Lightfoot, H. W., \& Kay, J. M. (2009b). Servitized manufacture: practical challenges of delivering integrated products and services. Proceedings of the Institution of Mechanical Engineers, Part B: Journal of Engineering Manufacture, 223(9), 1207-1215.

Baines, T. S., Wilson, H., Walton, I. M., Tranfield, D., Michele, P., Martinez, V., et al. (2007). State-of-the-art in product-service systems. Proceedings of the Institution of Mechanical Engineers, Part B: Journal of Engineering Manufacture, 221(10), 1543-1552.

Boulton, W. (1996). Xerox Corporation Surviving the Competitive Crisis1. The Thomas Walter Center for Technology Management.

Brewer, C. (2009, Printers vs. Copiers: The Saga Continues. ENX Magazine.

Chesbrough, H., \& Rosenbloom, R. S. (2002). The role of the business model in capturing value from innovation: evidence from Xerox Corporation's technology spin-off companies. Industrial and Corporate Change, 11(3), 529-555.

Davies, A., Brady, T., \& Hobday, M. (2007). Organizing for solutions: Systems seller vs. systems integrator. Industrial Marketing Management, 36(2), 183-193.

Fernandes, L., \& Longbottom, C. (2012a). Channel Managed Print Services. Quocirca Ltd.

Fernandes, L., \& Longbottom, C. (2012b). Vendor Landscape: Managed Print Services. Quocirca Ltd.

Finne, M., Brax, S., \& Holmström, J. (2013). Reversed servitization paths: a case analysis of two manufacturers. Service Business.

Fischer, T., Gebauer, H., Gregory, M., Ren, G., \& Fleisch, E. (2010). Exploitation or exploration in service business development?: Insights from a dynamic capabilities perspective. Journal of Service Management, 21(5), 591-624.

Gebauer, H., Paiola, M., \& Edvardsson, B. (2010). Service business development in small and medium capital goods manufacturing companies. Managing Service Quality, 20(2), 123-139.

Geum, Y., Lee, S., Kang, D., \& Park, Y. (2011). The customisation framework for roadmapping product-service integration. Service Business, 5(3), 213-236.

IDC (2012). Worldwide Page Volume Declined Slightly in 2011, But Developing Regions, Color, and MFP Segments Remain Growth Drivers, According to IDC http://www.idc.com/getdoc.jsp?containerId=prUS23743012. Accessed 27/05/2013.

IDC (2013). Worldwide Quarterly Hardcopy Peripherals Tracker. IDC.

Johnstone, B. (2004). Canon, lone wolf. WIRED, 2(10).

Kearns, D., \& Nadler, D. (1992). Prophets in the dark: how Xerox reinvented itself and beat back the Japanese. New York: Harper Business.

Kidambi, N. (2013). Race to the future: Multi-Functional Printing market. In H. Technologies (Ed.): HCL Technologies.

Kim, E., Lam, L.-1., Mitani, T., Li, Y., Choudhury, A., \& Shah, Z. (2012). Market Share: Printers, Copiers and MFPs, United States. Printing Hardware Worldwide: Gartner, Inc.

Le Clair, C. (2012). The Forrester Wave ${ }^{\mathrm{TM}}$ : Managed Print Services, Q2 2012. In I. Forrester Research (Ed.): Forrester Research, Inc.

Lightfoot, H. W., Baines, T., \& Smart, P. (2011). Examining the information and communication technologies enabling servitized manufacture. Proceedings of the Institution of Mechanical Engineers, Part B: Journal of Engineering Manufacture, 225(10), 1964-1968.

Markides, C. (1997). Strategic Innovation. Sloan Management Review, Spring, 9-23.

Markides, C. (1999). Six principles of breakthrough strategy. Business Strategy Review, 10(2), 1 10.

Martinez, V., Bastl, M., Kingston, J., \& Evans, S. (2010). Challenges in transforming manufacturing organisations into product-service providers. Journal of Manufacturing Technology Management, 21(4), 449-469.

Matsumoto, M., \& Kamigaki, K. (2013). Development and changes in the industrial product service systems - A case study of the photocopier PSS (The Philosopher's Stone for Sustainability.). Berlin

Matthyssens, P., \& Vandenbempt, K. (2010). Service addition as business market strategy: identification of transition trajectories. Journal of Service Management, 21(5), 693-714. 
Mont, O. (2004). Product-Service Systems: Panacea or Myth? PhD dissertation, The international institute for industrial environmental economics, Lund University, Sweden.

Moschella, D., Doug Neal, Piet Opperman, \& Taylor, J. (2004). The 'Consumerization'of Information Technology.". Leading Edge Forum.

Muscolino, H. (2011). IDC MarketScape: Worldwide Managed Print Services 2011 Hardcopy Vendor Analysis. IDC.

Neely, A. (2009). Exploring the financial consequences of the servitization of manufacturing. Operations Management Research, 1(2), 103-118, doi:10.1007/s12063-009-0015-5.

Oliva, R., \& Kallenberg, R. (2003). Managing the transition from products to services. International Journal of Service Industry Management, 14(2), 160-172.

Ortt, R. (2007). Strategies to commercialise breakthrough technologies. International Association for Management of Technology Proceedings, 2029-2048.

Owen, D. (2004). How a Lone Inventor and an Unknown Company Created the Biggest Communication Breakthrough Since Gutenberg: Chester Carlson and the Birth of the Xerox Machine. New York: Simon \& Schuster.

Paiola, M., Saccani, N., Perona, M., \& Gebauer, H. (2013). Moving from products to solutions: Strategic approaches for developing capabilities. European Management Journal, 31(4), 390409.

Park, Y., Geum, Y., \& Lee, H. (2012). Toward integration of products and services: Taxonomy and typology. Journal of Engineering and Technology Management, 29(4), 528-545.

Penttinen, E., \& Palmer, J. (2007). Improving firm positioning through enhanced offerings and buyer-seller relationships. Industrial Marketing Management, 36(5), 552-564.

Rapaccini, M., Saccani, N., Pezzotta, G., Burger, T., \& Ganz, W. (2013). Service development in product-service system a maturity model. The Service Industries Journal, 33(3-4), 300-319.

Rogowsky, R. A. (2009). Multifunction Products. Industry \& Trade Summary. United States International Trade Commission.

Sampson, S. (2001). Understanding Service Business 2nd ed. US: John Wiley \& Sons.

Sampson, S. (2013). Essentials of Service Design: Developing high-value service businesses with PCN Analysis: CreateSpace

Santamaría, L., Jesús Nieto, M., \& Miles, I. (2012). Service innovation in manufacturing firms: Evidence from Spain. Technovation, 32(2), 144-155, doi:10.1016/j.technovation.2011.08.006.

Shah, Z., Lam, L.-1., Mitani, T., Li, Y., Choudhury, A., \& Kim, E. (2013). Market Share: Printers, Copiers and MFPs, EMEA, 2012 Update. Printing Hardware Worldwide: Gartner, Inc.

Shepherd, C., \& Ahmed, P. (2000). From product innovation to solutions innovation a new paradigm for competitive advantage. European Journal of Innovation Management, 3(2), 6.

Spring, M., \& Araujo, L. (2009). Service, services and products: rethinking operations strategy. International Journal of Operations \& Production Management, 29(5), 444-467.

Storbacka, K. (2011). A solution business model: Capabilities and management practices for integrated solutions. Industrial Marketing Management, 40(5), 699-711.

Tom, W. (2001). The 1975 Xerox consent decree: ancient artifacts and current tensions. Antitrust Law J, 68(3), 967-990.

Tukker, A. (2004). Eight types of product-service system: eight ways to sustainability? Experiences from SusProNet. Business Strategy and the Environment, 13(4), 246-260.

Vandermerwe, S., \& Rada, J. (1988). Servitization of business: Adding value by Adding Services. European Management Journal, 6(4).

Visintin, F. (2012). Providing integrated solutions in the professional printing industry: The case of Océ. Computers in Industry, 63(4), 379-388.

Weilerstein, K., \& Drew, C. (2012). Magic Quadrant for Managed Print Services, Worldwide. Gartner, Inc.

Xerox (2011). Annual Report.

Xerox (2012). Annual Report. 